\title{
PREVALENCE AND PREDICTORS OF EXCLUSIVE BREASTFEEDING PRACTICES IN SEBERANG ULU I, PALEMBANG: A CROSS-SECTIONAL STUDY
}

\author{
Indah Purnama Sari, ${ }^{1}$ Dewi Handayani, ${ }^{2}$ Fatmalina Febry ${ }^{3}$ \\ ${ }^{1,3}$ Study Program of Nutrition, Public Health Faculty, Universitas Sriwijaya \\ ${ }^{2}$ Master's Degree from Public Health Faculty, Universitas Sumatera Utara
}

\begin{abstract}
Exclusive breastfeeding is one of the successful indicators in improving the health of babies. From 2013 until 2014, the practice of exclusive breastfeeding has decreased in Indonesia and has not reached the national targets of around $80 \%$ of babies being exclusively breastfed. This study aimed to identify the prevalence and determinants of exclusive breastfeeding in Seberang Ulu I, Palembang. A community-based cross sectional study was executed from July 5, 2016 to August 5, 2016 among mothers who had infants aged less than six months. A purposive sampling technique was used to select a sample of 125 participants. Data were collected using a structured questionnaire by the face-to-face interview technique. Bivariate and multiple logistic regression analysis were used to determine factors associated with the practice of breastfeeding exclusively and to control confounding effects. The prevalence of exclusive breastfeeding was $26.4 \%$ (95\% CI: $20.0 \%$ $35.1 \%$ ). After adjusting for confounders (mothers' attitudes and health workers' support), mothers who had good knowledge were 11.66 times more likely to breastfeed exclusively than those who had poor knowledge (AOR: 11.66, 95\% CI: 3.07-44.31). The prevalence of exclusive breastfeeding in Seberang Ulu I, ${ }^{1}$ Palembang, was still very low and has not reached the national target. The recommendation is to maximize the role of health workers in providing information about exclusive breastfeeding, so that they can continue providing motivation for mothers, husbands and families, so that the success and sustainability of exclusive breastfeeding practices could be achieved.
\end{abstract}

Keywords: Mother's knowledge, mother's attitude, health workers support, exclusive breastfeeding

\section{PREVALENSI DAN PREDIKTOR PEMBERIAN ASI EKSKLUSIF DI SEBERANG ULU I, PALEMBANG: STUDI CROSS-SECTIONAL}

\begin{abstract}
ABSTRAK
Pemberian ASI eksklusif merupakan salah satu indikator keberhasilan upaya peningkatan kesehatan bayi. Dalam kurun waktu tahun 2013 sampai dengan tahun 2014, terjadi penurunan cakupan pemberian ASI eksklusif di Indonesia. Hasil cakupan tersebut masih dibawah target program secara nasional yaitu sebanyak 80\% bayi diberikan ASI eksklusif. Penelitian ini bertujuan untuk mengidentifikasi prevalensi dan determinan praktik pemberian ASI eksklusif di Kecamatan Seberang Ulu I, Palembang. Studi potong lintang berbasis masyarakat telah dilaksanakan dari tanggal 5 Juli 2016 sampai 5 Agustus 2016 pada ibu yang memiliki bayi berusia 0-6 bulan. Teknik pengambilan sampel secara tidak acak digunakan untuk memilih 125 responden. Data dikumpulkan menggunakan kuesioner terstruktur melalui teknik tatap muka. Analisis bivariat dan regresi logistik ganda digunakan untuk mengetahui faktor yang berhubungan dengan praktik pemberian ASI eksklusif dan untuk mengendalikan efek perancu. Prevalensi pemberian ASI eksklusif sebesar 26.4\% (95\% CI: $20.0 \%-35.1 \%$ ). Setelah mengontrol efek perancu (sikap ibu dan dukungan petugas kesehatan), ibu berpengetahuan baik berkemungkinan 11.66 kali lebih tinggi untuk dapat memberikan ASI eksklusif dibandingkan ibu berpengetahuan kurang baik $\left(\mathrm{OR}_{\mathrm{a}}: 11.66,95 \% \mathrm{CI}: 3.07-44.31\right)$. Prevalensi pemberian ASI eksklusif di Kecamatan Seberang Ulu I, Palembang masih rendah dan belum mencapai target nasional. Adapun saran yang dapat diberikan adalah memaksimalkan peran tenaga kesehatan dalam memberikan informasi mengenai ASI eksklusif sehingga tenaga kesehatan dapat terus memotivasi para ibu, suami dan keluarga, yang akhirnya keberhasilan dan keberlangsungan praktik pemberian ASI eksklusif dapat tercapai.
\end{abstract}

Kata kunci: Pengetahuan ibu, sikap ibu, dukungan tenaga kesehatan, ASI eksklusif

\footnotetext{
${ }^{1}$ Correspondece Address: Indah Purnama Sari Street Palembang Prabumulih KM 32, Indralaya District Ogan Ilir, South Sumatera Email: indah_purnamasari@fkm.unsri.ac.id
} 


\section{INTRODUCTION}

Exclusive breastfeeding is the practice of giving only breast milk to infants in their first six months of life (no other food or water). ${ }^{1}$ Being breastfed exclusively is also a key indicator of childhood survival, nutrition, early growth and development. It not only provides infants with the best start in their life but also has benefits for mothers, protects against non-communicable diseases and contributes to environmental sustainability. ${ }^{2}$ Exclusive breastfeeding has a significant impact on the reduction of morbidity and mortality from diarrhea and pneumonia. ${ }^{3}$

Improvements in breastfeeding rates are critical to the attainment of the Post-2015 Sustainable Development Goals due to the fact that global breastfeeding rates have seen only slow progress since 1995. Globally, fewer than $40 \%$ of infants aged 0 to six months are exclusively breastfed. ${ }^{2}$ Indonesia, a developing country, has more infants who are non-exclusively breastfed than the Philippines and Vietnam. ${ }^{3}$ In Indonesia, based on data from Ministry of Health, the coverage of exclusive breastfeeding in 2014 (52.3\%) decreased compared to the coverage of exclusive breastfeeding in 2013 (54.3\%). This means that only $52.3 \%$ of infants are breastfed to six months of age. The coverage is still below the national target of $80 \%$ of infants being given breast milk from birth to six months of age (exclusive breastfeeding). ${ }^{4}$ Many factors can affect the practice of exclusive breastfeeding by mothers, such as socio-demographic, knowledge, attitude, and husbands', families' (mother's or mother-inlaw's) and health workers' support. ${ }^{5-13}$

South Sumatera Province is one of the provinces that focus on exclusive breastfeeding due to the low coverage of exclusive breastfeeding in 2014 , at $64.5 \% .^{4}$ The coverage of exclusive breastfeeding for Palembang City in 2014 was $74.18 \%$. Seberang Ulu I sub-district is one of the subdistricts under the auspices of the City Health
Office of Palembang. Based on the Health Profile of Palembang City in 2014, it was found that Seberang Ulu I sub-district was one of the sub-districts with exclusive breastfeeding coverage $(72.87 \%)$ that was lower than Palembang City. ${ }^{14}$ Therefore, strategies were needed to promote and support exclusive breastfeeding, not only to increase the coverage of infants less than six months being exclusively breastfed, but also to decrease the morbidity and mortality of infants. The aim of this study was to identify the prevalence of exclusive breastfeeding and to determine the predictors among mothers of infants less than six months of age in Seberang Ulu I sub-district, Palembang, Indonesia.

\section{METHOD}

\section{Study Design and Sampling Procedure}

This was a community-based crosssectional study held from July 5 to August 5, 2016, in Seberang Ulu I sub-district, Palembang. The populations were all mothers of children who had been born alive. Samples were mothers of infants who had been aged 7 months until 11 months who fulfilled the inclusion criteria, such as infants with single birth or who were either the first or the last child in the family. While exclusion criteria were infants with infectious diseases (diarrhea and Acute Respiratory Duct Infection) and those who had a single parent. The sample size was calculated using hypothesis tests for two population proportions. In a previous study conducted by Tewabe ${ }^{15}$, the prevalence of exclusive breastfeeding among mothers who had and had not received breastfeeding counseling during antenatal care was found to be about $64 \%$ and $38 \%$, respectively. Given the $95 \%$ confidence intervals (CI), the $80 \%$ power of the test and a $10 \%$ non-response rate, the final sample size was about 125 eligible mothers, selected by purposive sampling. 


\section{Data Collection Instruments and Data Collection Procedure}

Data were collected during house visits by face-to-face interviews using a structured interviewer-administered questionnaire. A content and construct validity test was performed to ensure the validity and reliability of the questionnaire. To ensure that the questionnaire was systematic, it was divided into seven parts for the respondents to answer. Part A was about socio-demographic characteristics such as age of mother, occupation, monthly income, and education level, parity, birth attendants, place of birth, and types of birth. Part B was about exclusive breastfeeding practice, which included breastfeeding after birth, one hour after birth, until two months, two to four months, four to six months, and types of foods and drinks that were consumed by infants. Exclusive breastfeeding practice means that mothers give infants only breast milk until the age of six months. Infants who had received breast milk exclusively until six months of age were coded ' 1 ' while those that had not been exclusively breastfed were coded ' 0 '.

Part C, D, E, F and G are categorized into 2 categories which previously tested using Kolmogorov-Smirnov test to investigate the normal distribution of the data. The mean was used if data normally distributed and the median if data didn't fitted normal distribution. Part C was about mothers' knowledge, which consisted of 21 questions; each correct answer was given a score of 1 and a score of 0 was given for each incorrect answer. After totaling the scores and median (18.00), it was dichotomized into good knowledge $\geq$ median and poor knowledge < median. Part D was about mothers' attitudes, which consisted of 20 questions. Each item of the question was based on Likert's scale, ranging from 1 to 5 , strongly disagree (1), disagree (2), neutral (3), agree (4), and strongly agree (5) for positive questions and counterparts for negative questions. After totaling the scores and mean (56.37), it was dichotomized into positive $\geq$ mean and less positive < mean. Parts E, F and G were about husbands' support (25 questions), families' support (20 questions), and health workers' support (17 questions) that used a scale ranging from 1 to 3 with never (1), sometimes (2) and often (3) for positive questions and counterparts for negative questions. After totaling the scores of husbands' support (mean (34.15)), families' support (median (31.00)), and health workers' support (mean (25.00), it was dichotomized into yes $\geq$ mean/median and no $<$ mean/median. All respondents were briefed about the objectives of the study and written informed consent was obtained prior to data collection.

\section{Data Processing and Analysis}

The collected data were checked and verified manually. Any inconsistencies and inaccuracies were corrected the following day. After that, completed data were coded and entered on the computer using statistical software. Before data analysis, the data were crosschecked for any unusual findings. Descriptive statistics were used to identify the socio-demographic characteristics, mothers' knowledge and attitudes, support of husbands, families and health workers, and the prevalence of exclusive breastfeeding. To determine factors associated with exclusive breastfeeding practice, binary logistic regression was used. Two models were run: the first model was performed to determine each independent variable with the outcome variables, which were included in the second, final model (using multiple logistic regression). The strength of association was measured using adjusted odds ratio (AOR) with $95 \%$ confidence intervals (CI). The pvalue of less than 0.05 was declared as a significant association. 


\section{RESULTS}

\section{Socio-demographic Characteristics}

A total of 125 mothers with infants of age 7-11 months were interviewed. Around seven-ninths $(77.6 \%)$ of mothers were delivered at the age of 20-35 years. Regarding educational status, $74(59.2 \%)$ of the mothers had higher than secondary education and a majority $(86.4 \%)$ of the study participants were unemployed. Around three-quarters
(75.2\%) of the mothers earned a monthly household income less than the City Minimum Wage of Palembang: about 169.30 USD. More than seven-tenths $(70.4 \%)$ of mothers had more than two children and 105 (84\%) mothers delivered by vaginal birth (normally). Most (96.8\% and 98.4\%) of the mothers were delivered in the health facility and had a health worker as a birth attendant (Table 1).

Table 1.

Socio-demographic characteristics among mothers of infants aged less than six months, Seberang Ulu I, Palembang, $2016(n=125)$

\begin{tabular}{|c|c|c|c|}
\hline Variables & Category & Total (n) & Percentage (\%) \\
\hline \multirow[t]{2}{*}{ Maternal age (in years) } & $20-35$ & 97 & 77.6 \\
\hline & $<20$ and or $>35$ & 28 & 22.4 \\
\hline \multirow[t]{2}{*}{ Maternal education } & Secondary education and above & 74 & 59.2 \\
\hline & Primary education and lower & 51 & 40.8 \\
\hline \multirow[t]{2}{*}{ Maternal occupation } & Unemployed & 108 & 86.4 \\
\hline & Employed & 17 & 13.6 \\
\hline \multirow[t]{2}{*}{ Monthly household income (USD) } & Less than 169.30 & 94 & 75.2 \\
\hline & More than 169.30 & 31 & 24.8 \\
\hline \multirow[t]{2}{*}{ Number of children } & 2 and above & 88 & 70.4 \\
\hline & Only 1 & 37 & 29.6 \\
\hline \multirow[t]{2}{*}{ Mode of delivery } & Normal/ vaginal & 105 & 84 \\
\hline & Caesarian section & 20 & 16 \\
\hline \multirow[t]{2}{*}{ Place of birth } & Health facility & 121 & 96.8 \\
\hline & Home & 4 & 3.2 \\
\hline \multirow[t]{2}{*}{ Birth attendants } & Health workers & 123 & 98.4 \\
\hline & Non health workers & 2 & 1.6 \\
\hline
\end{tabular}

\section{Prevalence and Predictors of Exclusive Breastfeeding Practice}

The prevalence of exclusive breastfeeding practice in Seberang Ulu I subdistrict was $26.4 \%$ (95\% CI: $20.0 \%-35.1 \%$ ). More than half, $51.2 \%$ and $54.4 \%$, of mothers reported they had good knowledge of and

\section{Table 2.}

Prevalence and predictors of exclusive breastfeeding practice among mothers of infants aged less than six months, Seberang Ulu I, Palembang, $2016(n=125)$

\begin{tabular}{llcc}
\hline Variables & Category & Total (n) & Percentage (\%) \\
\hline Exclusive breastfeeding practice & Yes & 33 & 92 \\
& No & 64 & 73.6 \\
Mothers' knowledge & Good knowledge & 61 & 51.2 \\
& Poor knowledge & 68 & 48.8 \\
Mothers' attitude & Positive & 57 & 54.4 \\
& Less positive & 66 & 52.6 \\
Husbands' support & Yes & 59 & 47.2 \\
& No & 66 & 52.8 \\
Family support & Yes & 59 & 47.2 \\
& No & 66 & 52.8 \\
Health workers' support & Yes & 59 & 47.2 \\
\hline
\end{tabular}

attitudes about exclusive breastfeeding, respectively. While 66 (52.8\%) mothers had their husbands' support, they also had the support of their families and health workers for feeding their infants only breast milk until the age of six months (Table 2). 
Factors Associated with Exclusive Breastfeeding Practice

The independent variables of the practice of exclusive breastfeeding were maternal age, education, occupation, monthly household income, number of children, mode of delivery, place of birth, birth attendants, mother's knowledge, mother's attitude, and husband's, family's and health workers' support. In the bivariate logistic regression, only mother's knowledge and attitude were significantly associated with exclusive breastfeeding practice $\quad(\mathrm{p}$-value $<0.05)$. However, all of the independent variables

Table 3.

Factors associated with exclusive breastfeeding practice of mothers of infants aged less than six months, Seberang Ulu I, Palembang, 2016

\begin{tabular}{|c|c|c|c|c|c|}
\hline \multirow{3}{*}{ Variables } & \multirow{3}{*}{ Category } & \multicolumn{2}{|c|}{$\begin{array}{c}\text { Exclusive Breastfeeding } \\
\text { Practice }\end{array}$} & \multirow{3}{*}{$\mathrm{OR}_{\mathrm{c}}(\mathbf{9 5 \%} \mathrm{CI})$} & \multirow{3}{*}{$\mathrm{OR}_{\mathrm{a}}(95 \% \mathrm{CI})$} \\
\hline & & Yes & No & & \\
\hline & & $(\mathbf{n} \& \%)$ & $(\mathbf{n} \& \%)$ & & \\
\hline \multirow{2}{*}{$\begin{array}{l}\text { Maternal age (in } \\
\text { years) }\end{array}$} & $20-35$ & $26(26.8)$ & $71(73.2)$ & $1.09(0.42-2.89)$ & \multirow{2}{*}{-} \\
\hline & $<20$ and or $>35$ & $7(25.0)$ & $21(75.0)$ & 1 & \\
\hline \multirow{2}{*}{ Maternal education } & Secondary education and above & $23(31.1)$ & $51(68.9)$ & $1.85(0.79-4.32)$ & \multirow{2}{*}{-} \\
\hline & Primary education and lower & $10(19.6)$ & $41(80.4)$ & 1 & \\
\hline \multirow{2}{*}{ Maternal occupation } & Unemployed & $28(25.9)$ & $80(74.1)$ & $0.84(0.27-2.59)$ & \multirow{2}{*}{-} \\
\hline & Employed & $5(29.4)$ & $12(70.6)$ & 1 & \\
\hline \multirow{2}{*}{$\begin{array}{l}\text { Monthly household } \\
\text { income (USD) }\end{array}$} & Less than 169.30 & $24(25.5)$ & $70(74.5)$ & $0.84(0.34-2.07)$ & \\
\hline & More than 169.30 & $9(29.0)$ & $22(71.0)$ & 1 & \\
\hline \multirow{2}{*}{ Number of children } & 2 and above & $23(26.1)$ & $65(73.9)$ & $0.96(0.40-2.28)$ & \multirow{2}{*}{-} \\
\hline & Only 1 & $10(27.0)$ & $27(73.0)$ & 1 & \\
\hline \multirow{2}{*}{ Mode of delivery } & Normal/ vaginal & $29(27.6)$ & $76(72.4)$ & $1.53(0.47-4.95)$ & \multirow{2}{*}{-} \\
\hline & Caesarian section & $4(20.0)$ & $16(80.0)$ & 1 & \\
\hline \multirow{2}{*}{ Place of birth } & Health facility & $32(26.4)$ & $89(73.6)$ & $1.08(0.11-10.75)$ & \multirow{2}{*}{-} \\
\hline & Home & $1(25.0)$ & $3(75.0)$ & 1 & \\
\hline \multirow{2}{*}{ Birth attendants } & Health workers & $33(26.8)$ & $90(73.2)$ & \multirow{2}{*}{-} & \multirow{2}{*}{-} \\
\hline & Non health workers & $0(0.0)$ & $2(100.0)$ & & \\
\hline \multirow{2}{*}{$\begin{array}{l}\text { Mother's } \\
\text { knowledge }\end{array}$} & Good knowledge & $28(43.8)$ & $36(56.3)$ & $8.71(3.08-24.64) *$ & $11.66(3.07-44.31)^{*}$ \\
\hline & Poor knowledge & $5(8.2)$ & $56(91.8)$ & 1 & 1 \\
\hline \multirow{2}{*}{ Mother's attitude } & Good attitude & $24(35.3)$ & $44(64.7)$ & $2.91(1.22-6.93)^{*}$ & $0.82(0.25-2.69)$ \\
\hline & Poor attitude & $9(15.8)$ & $48(84.2)$ & 1 & 1 \\
\hline \multirow{2}{*}{ Husband's support } & Yes & $21(31.8)$ & $45(68.2)$ & $1.83(0.81-4.14)$ & \multirow{2}{*}{-} \\
\hline & No & $12(20.3)$ & $47(79.7)$ & 1 & \\
\hline \multirow{2}{*}{ Family support } & Yes & $20(30.3)$ & $46(69.7)$ & $1.54(0.69-3.46)$ & \multirow{2}{*}{-} \\
\hline & No & $13(22.0)$ & $46(78.0)$ & 1 & \\
\hline \multirow{2}{*}{$\begin{array}{l}\text { Health worker's } \\
\text { support }\end{array}$} & Yes & $19(28.8)$ & $47(71.2)$ & $1.29(0.58-2.89)$ & $0.64(0.25-1.66)$ \\
\hline & No & $14(23.7)$ & $45(76.3)$ & 1 & 1 \\
\hline
\end{tabular}

$=$ reference, $*=\mathrm{p}$-value $<0.05, \mathrm{n}=$ total, $\%=$ percent were included in the multiple logistic regression models. While each independent variable was adjusted for other variables, mother's knowledge was a dominant variable associated with exclusive breastfeeding practice after adjusted by mother's attitude and health workers' support (95\% confidence level and a p-value < 0.05). Mothers who had good knowledge were 11.66 times more likely to breastfeed exclusively than those who had poor knowledge, after adjusted by mother's attitude and health workers' support $\left(\mathrm{OR}_{\mathrm{a}}\right.$ : 11.66, 95\% CI: 3.07-44.31) (Table 3). 


\section{DISCUSSION}

Exclusive breastfeeding is the provision of breast milk given to infants from birth for six months, without adding and/or replacing with other foods or beverages. The prevalence of exclusive breastfeeding in this study was less than one-third, $26.4 \%$, which is lower than Indonesia's national target level of $80 \%{ }^{4}$ It is also lower than declared in early international studies in Ethiopia (74.1\%), ${ }^{16}$ Hawassa Southern Ethiopia (60.9\%), ${ }^{17}$ Lebanon $(27,4 \%)^{18}$, Bahir Dar City Ethiopia $(50,3 \%)^{19}$, Halaba Ethiopia $(70.5 \%),{ }^{20}$ Magelang City of Indonesia $(27.4 \%),{ }^{21}$ Gianyar District of Indonesia (31.9\%), ${ }^{22}$ Ghana (27.7\%). ${ }^{6}$ But it is higher than the prevalence in Congo (2.8\%), ${ }^{23}$ Canada $(15.3 \%),{ }^{24}$ and City of Palu, Central Sulawesi, Indonesia $(26.2 \%) .{ }^{8}$ This variation might be due to methodological differences, time, economic status, and social-cultural differences.

Mother's knowledge was one variable that became the focus in this research. Knowledge is the result of human sensing or one's experience of the object through the five senses (sight, smell, taste, touch and hearing) at the time of sensing and being strongly influenced by the intensity of attention and perception of the object. ${ }^{25}$ In this study, mothers who had good knowledge practiced exclusive breastfeeding $(51.2 \%)$, as opposed to those who had poor knowledge (48.8\%). This result is similar to studies from Ethiopia, ${ }^{9,26}$ Congo, ${ }^{23}$ Myanmar, ${ }^{27}$ Ghana, ${ }^{28}$ and Indonesia. ${ }^{21}$ The results of this study showed that about $16.0 \%$ of mothers said that colostrum should not be given to infants and $14.4 \%$ of them said that colostrum should be discarded. This indicated that the mothers' knowledge about breast milk, especially colostrum, was inadequate. It is very important that mothers, especially young mothers, receive adequate information on the nutrition content of colostrum and breast milk as a whole, so that infants can be exclusively breastfed until the age of six months. In addition to the mother's knowledge, the husband's and family's support plays an important role in the continuity of exclusive breastfeeding practices. Husbands can provide support to improve mothers' knowledge by helping to find out information about the importance of exclusive breastfeeding and how to breastfeed the baby properly. The results showed that only $16.8 \%$ of mothers receive this support from their husbands.

After an adjustment was made using a multiple logistic regression model, mothers' attitudes associated with breastfed exclusively for infants in the first their six months. More than half $(54.4 \%)$ of mothers in Seberang Ulu I sub-district, Palembang had a positive attitude to the practice of exclusive breastfeeding. Bivariate logistic regression showed that mothers with a positive attitude were 2.91 times more likely to breastfeed their infants exclusively compared to those who with a negative attitude $\left(\mathrm{OR}_{\mathrm{c}}: 2.91,95 \% \mathrm{CI}\right.$ : 1.22-6.93). While in multiple logistic regression, mothers' attitude was a confounder. This result was consistent with the previous studies done in Indonesia, ${ }^{29}$ Ireland, ${ }^{30}$ Lebanon, ${ }^{18}$ and Ethiopia. ${ }^{26}$ This study also found that almost four-fifths (77.6\%) of mothers showed that they had a feeling of excitement when giving breastfed exclusively to their babies and $63.2 \%$ of mothers believed that infants who had been exclusively breastfed were healthier than those who had been fed formula milk. However, the results showed that among mothers with a positive attitude toward exclusive breastfeeding practices, $64.7 \%$ of mothers did not exclusively breastfed. This shows that not all positive attitudes will result in positive behavior. This is because that attitude is a reaction or response to a stimulus or object that is still undiscovered. ${ }^{25}$

Along with mothers' knowledge and attitude, health workers' support was one of 
the supporting factors for the continuity of exclusive breastfeeding. The results showed that almost all mothers received information on exclusive breastfeeding from health workers at the time of pregnancy. About $92.0 \%$ of mothers said that health workers provided information about giving breastfeeding to infants, and $94.4 \%$ of mothers said that health workers recommended giving colostrum to babies. This study is also consistent with previous studies in Ethiopia ${ }^{15}$ and Myanmar $^{27}$ that concluded that health workers' support is associated with the exclusive breastfeeding of infants. It means that health workers not only have an important role to play in improving the quality of health services to mothers, but also play a role in raising people's awareness, willingness and ability to live healthily. The optimum degree of health is an investment in the development of human resources, so that people are productive, both socially and economically.

\section{REFERENCES}

1. WHO \& UNICEF. WHA Global Nutrition 2025: Breastfeeding Policy Brief. Geneva: World Health Organization; 2014.

2. WHO \& UNICEF. Breastfeeding Advocacy Initiative for the Best Start in Life. Geneva: World Health Organization; 2015.

3. UNICEF. Infant and Young Child Feeding. New York: UNICEF; 2011.

4. Ministry of Health Republic of Indonesia. Indonesia Health Profile 2014. Jakarta: Ministry of Health Republic of Indonesia; 2015.

5. Hussein $\mathrm{TH}$, Mgongo $\mathrm{M}$, Uriyo JG, Damian DJ, Stray-Pedersen B, Msuya SE, et al. Exclusive Breastfeeding Rates and Factors Associated with Exclusive Breastfeeding Practices in Northern Tanzania: Measurement using Two Different Methodologies-24 Hours Recall and Recall Since Birth.

\section{CONCLUSION}

This study concludes that the prevalence of exclusive breastfeeding in Seberang Ulu I sub-district of Palembang is still very low and has not reached the national target. Mothers' knowledge is a dominant variable with exclusive breastfeeding, while mothers' attitude and health workers' support also affects exclusive breastfeeding practices. Mothers' knowledge and attitude are also related to husbands', families' and health workers' support, which can motivate mothers to breastfeed their babies exclusively. The advice from this study is to maximize the role of health workers in providing information about exclusive breastfeeding, aimed not only at the mother, but also at the nearest family members (husband, mother, mothers-in-law). In addition, health workers need to take a refresher course related to the practice of exclusive breastfeeding, so that they can continue to provide motivation for mothers, husbands and families, leading to the success and sustainability of exclusive breastfeeding practices.

International Journal of MCH and AIDS. 2019;8(1):32-43.

6. Nukpezah R, Nuvor SV, Ninnoni JP. Knowledge and Practice of Exclusive Breastfeeding among Mothers in the Tamale Metropolis of Ghana. Reproductive Health. 2018;15:140.

7. Mohamed MJ, Ochola S, Owino VO. Comparison of Knowledge, Attitudes and Practices on Exclusive Breastfeeding between Primiparous and Multiparous Mothers Attending Wajir District hospital, Wajir County, Kenya: A CrossSectional Analytical Study. International Breastfeeding Journal. 2018;13(1):11.

8. Rahman N, Dewi NU, Fitrasyah SI, Bohari B, Rifai M. Factors Related to Exclusive Breastfeeding among Mothers in the City of Palu, Central Sulawesi, Indonesia. Malaysian Journal of Nutrition. 2017;23:175-89.

9. Mekuria G, Edris M. Exclusive 
Breastfeeding and Associated Factors among Mothers in Debre Markos, Northwest Ethiopia: A Cross-Sectional Study. International Breastfeeding Journal. 2015;10(1):1-7.

10. Ramadani M, Hadi EN. Husband Support for Exclusive Breastfeeding Practice in Air Tawar Public Health Care in Padang City, West Sumatera. KESMAS, Jurnal Kesehatan Masyarakat Nasional. 2010;4(6):269-74.

11. Mannion CA, Hobbs AJ, McDonald SW, Tough SC. Maternal Perceptions of Partner Support during Breastfeeding. International Breastfeeding Journal. 2013;8(1):4.

12. Daly A, Pollard CM, Phillips M, Binns CW. Benefits, Barriers and Enablers of Breastfeeding: Factor Analysis of Population Perceptions in Western Australia. PLoS One. 2014;9(2):1-10.

13. Desai A, Mbuya MNN, Chigumira A, Chasekwa B, Humphrey JH, Moulton LH, et al. Traditional Oral Remedies and Perceived Breast Milk Insufficiency are Major Barriers to Exclusive Breastfeeding in Rural Zimbabwe. The Journal of Nutrition. 2014;144(7):11139.

14. Palembang City Health Office. Palembang Health Profile 2014. Palembang: Palembang City Health Office; 2015.

15. Tewabe T, Mandesh A, Gualu T, Alem G, Mekuria G, Zeleke H. Exclusive Breastfeeding Practice and Associated Factors among Mothers in Motta town, East Gojjam Zone, Amhara Regional State, Ethiopia, 2015: A Cross-Sectional Study. International Breastfeeding Journal. 2017;12(1):12.

16. Tamir Hunegnaw M, Derseh Gezie L, Teferra A. Exclusive Breastfeeding and Associated Factors among Mothers in Gozamin District, Northwest Ethiopia: A Community Based Cross-Sectional Study. International Breastfeeding Journal. 2017;12.

17. Adugna B, Tadele $\mathrm{H}$, Alemayehu $\mathrm{F}$, Berhan Y. Determinants of Exclusive Breastfeeding in Infants less than Six Months of Age in Hawassa, An Urban Setting, Ethiopia. International Breastfeeding Journal. 2017;12.
18. Hamade H, Chaaya $M$, Saliba $M$, Chaaban R, Osman H. Determinants of Exclusive Breastfeeding in an Urban Population of Primiparas in Lebanon: A Cross-Sectional Study. BMC Public Health. 2013;13(1):702.

19. Seid AM, Yesuf ME, Koye DN. Prevalence of Exclusive Breastfeeding Practices and Associated Factors among Mothers in Bahir Dar city, Northwest Ethiopia: A Community Based CrossSectional Study. International Breastfeeding Journal. 2013;8(1):14.

20. Sonko A, Worku A. Prevalence and Predictors of Exclusive Breastfeeding for the First Six Months of Life among Women in Halaba Special Woreda, Southern Nations, Nationalities and Peoples' Region/SNNPR/, Ethiopia: A Community Based Cross-Sectional Study. Archives of Public Health. 2015;73.

21. Sriningsih I. Demographic Factors, Mothers' Knowledge about Breastmilk and Exclusive Breastfeeding Practice. KEMAS. 2011;6(2):100-6.

22. Cahyani NW, Widarsa IKT. The Application of Path Analysis in the Analysis of Determinant of Exclusivity of Breastfeeding in the Working Area of Puskesmas Payangan, Gianyar. Community Health (Bristol). 2014;2(1):96-106.

23. Babakazo P, Donnen P, Akilimali P, Mapatano Mala Ali N, Okitolonda E. Predictors of Discontinuing Exclusive Breastfeeding before Six Months among Mothers in Kinshasa: A Prospective Study. International Breastfeeding Journal. 2015;10.

24. Jessri M, Farmer A, Maximova K, D Willows N, Bell R. Predictors of Exclusive Breastfeeding: Observations from the Alberta pregnancy Outcomes and Nutrition (APrON) study. BMC Pediatrics. 2013;13:77.

25. Notoatmodjo S. Health Promotion and Behavior. Jakarta: PT. Rineka Cipta; 2007.

26. Chekol D, Biks G, Gelaw Y, Melsew Y. Exclusive Breastfeeding and Mothers' Employment Status in Gondar Town, Northwest Ethiopia: A Comparative Cross-Sectional Study. International 
Breastfeeding Journal. 2017;12.

27. Hmone MP, Li M, Agho K, Alam A, Dibley MJ. Factors Associated with Intention to Exclusive Breastfeed in Central Women's Hospital, Yangon, Myanmar. International Breastfeeding Journal. 2017;12(1):29.

28. Mogre V, Dery M, K. Gaa P. Knowledge, Attitudes and Determinants of Exclusive Breastfeeding Practice among Ghanaian Rural Lactating
Mothers. International Breastfeeding Journal. 2016;11.

29. Raharjo BB. Mother's Profile and Midwife's Role in the Early Initiation Breastfed and Exclusive Breastfeeding Practice. KEMAS. 2014;10(1):53-63.

30. Zhou Q, Younger KM, Kearney JM. An Exploration of the Knowledge and Attitudes towards Breastfeeding among a sample of Chinese Mothers in Ireland. BMC Public Health. 2010;10(1):722. 